\title{
Perbandingan Kemampuan Kitosan dari Limbah Kulit Udang dengan Aluminium Sulfat untuk Menurunkan Kekeruhan Air dari Outlet Bak Prasedimentasi IPAM Ngagel II
}

\author{
Cecilia Dwi Triastiningrum dan Alfan Purnomo \\ Teknik Lingkungan, Fakultas Teknik Sipil dan Perencanaan, Institut Teknologi Sepuluh Nopember (ITS) \\ Jl. Arief Rahman Hakim, Surabaya 60111 Indonesia \\ e-mail: alfan_p@enviro.its.ac.id
}

\begin{abstract}
Abstrak-Koagulan yang digunakan IPAM Ngagel II untuk mengolah air baku adalah aluminium sulfat. Penggunaan aluminium sulfat yang tidak sesuai dapat mempengaruhi $\mathrm{pH}$ air dan menyebabkan kerugian baik dalam sisi lingkungan maupun kesehatan konsumen. Di lain hal, terdapat pula masalah peningkatan jumlah limbah kulit udang yang berpotensi namun belum dimanfaatkan secara optimal. Dari masalah-masalah tersebut munculah ide untuk mencari alternatif koagulan yang ramah lingkungan, efektif, efisien dan sekaligus dapat memanfaatkan limbah kulit udang. Kitosan yang terdapat di kulit udang dapat dijadikan alternatif karena sifatnya tidak beracun, mudah terdegradasi dan bahan bakunya mudah didapatkan. Kitosan adalah senyawa polimer dengan ion positif yang diperoleh dari proses hidrolisis kitin menggunakan basa kuat sehingga terjadi deasetilasi gugus asetamida (NH-COCH$)$ menjadi gugus amina $\left(\mathrm{NH}_{2}\right)$. Kitosan diperoleh dari serbuk kulit udang yang melalui proses deproteinasi dengan $\mathrm{NaOH} 6 \%$, proses demineralisasi dengan $\mathrm{HCl} 1,1 \mathrm{~N}$, dan proses deasetilasi dengan $\mathrm{NaOH} 50 \%$. Kitosan yang dihasilkan kemudian di cek kualitasnya dengan melakukan uji kelarutan menggunakan $\mathrm{CH}_{3} \mathrm{COOH} 1 \%$ dan pengecekan derajat deasetilasi dengan metode titrasi asam basa. Efektifitas dan efisiensi kitosan diuji dengan metode jar test menggunakan sampel air yang berasal dari outlet bak prasedimentasi IPAM Ngagel 2. Aspek yang diuji adalah kekeruhan dan $\mathrm{pH}$ dengan variabel berupa dosis koagulan dan kekeruhan air. Dari sisi biaya, yang akan dibandingkan adalah biaya pemakaian koagulan per hari dan per jam. Penelitian ini membandingkan kemampuan kitosan dengan aluminium sulfat $\mathbf{4 5 \%}$ untuk menurunkan kekeruhan air dari outlet bak prasedimentasi IPAM Ngagel 2. Hasil penelitian menunjukkan bahwa aluminium sulfat $\mathbf{4 5 \%}$ lebih efektif dari kitosan, namun kitosan lebih efisien dari aluminium sulfat. Dari segi biaya, pemakaian aluminium sulfat $45 \%$ memakan biaya yang jauh lebih sedikit dibandingkan dengan pemakaian kitosan.
\end{abstract}

Kata Kunci-Aluminium Sulfat, Jar Test, Kekeruhan, Kitosan, Limbah Kulit Udang

\section{PENDAHULUAN}

A IR baku yang dipakai oleh PDAM Surya Sembada Surabaya berasal dari Kali Surabaya. Saat ini kualitas air Kali Surabaya masuk ke dalam golongan kelas II \& III, padahal sumber air baku setidaknya masuk ke dalam golongan kelas I [1]. Salah satu proses pengolahan yang dapat dilakukan untuk meningkatkan kualitas air baku adalah proses koagulasi dan flokulasi. Koagulan yang biasa dipakai oleh IPAM Ngagel II dalam proses koagulasi flokulasi adalah aluminium sulfat. Pemakaian aluminium sulfat dengan dosis yang tidak sesuai dapat menimbulkan beberapa kerugian seperti mempengaruhi $\mathrm{pH}$ air dan menambah residual kation dalam air. Sifat aluminium sulfat yang tidak mudah terdegradasi juga dapat merugikan lingkungan dan kesehatan konsumen [2].

Selain itu, terdapat pula masalah peningkatan jumlah limbah kulit udang yang dihasilkan dari program industrialisasi udang yang dijalankan pemerintah. Namun sayangnya, limbah tersebut selama ini belum dimanfaatkan secara optimal. Pada umumnya limbah kulit udang hanya dimanfaatkan sebagai bahan campuran kerupuk, terasi atau makanan ternak sehingga nilai ekonomisnya rendah.

Dari masalah-masalah tersebut maka diperlukan suatu koagulan alternatif yang tidak menyebabkan efek samping seperti penggunaan aluminium sulfat sekaligus dapat meningkatkan nilai ekonomis limbah kulit udang. Kitosan yang berasal dari limbah kulit udang dapat dijadikan sebagai koagulan alternatif karena sifatnya tidak beracun, mudah terdegradasi dan bahan bakunya mudah didapatkan. Pemakaian kitosan dengan dosis yang lebih rendah dari aluminium sulfat dapat menurunkan kekeruhan air dengan lebih efektif [3]. Penggunaan kitosan tidak mempengaruhi $\mathrm{pH}$ air, tidak menimbulkan residual kation logam dan menghasilkan lumpur dengan volume yang lebih sedikit. Kitosan dari kulit udang diperoleh dari beberapa tahapan proses, yaitu deproteinase, demineralisasi dan deasetilasi [4].

Penelitian ini bertujuan untuk membandingkan efektifitas, efisiensi dan biaya dari pemakaian kitosan dan aluminium sulfat $45 \%$ pada proses produksi IPAM Ngagel II.

\section{METODE PENELITIAN}

\section{A. Pembuatan Kitosan dari Limbah Kulit Udang}

Proses pembuatan kitosan dari limbah udang dilakukan melalui 3 tahap yaitu demineralisasi, deproteinasi dan deasetilasi kemudian dilanjutkan dengan karakterisasi kitosan 
untuk mengetahui tingkat kemurnian kitosan yang dihasilkan. Penjelasannya adalah sebagai berikut:

a. Penghilangan protein (deproteinasi)

Larutkan kulit udang dengan $\mathrm{NaOH}$ 6\% menggunakan rasio 1:10 (b/v), kemudian larutan tersebut dipanaskan dengan suhu $100^{\circ} \mathrm{C}$ selama 2 jam sambil terus diaduk. Setelah dipanaskan larutan didinginkan selama 30 menit lalu di saring dengan penyaring kain sambil dicuci dengan air keran sampai $\mathrm{pH}$ nya netral, kemudian dibilas dengan aquades. Selanjutnya kulit udang dikeringkan di dalam oven selama 24 jam dan ditimbang.

b. Penghilangan mineral (demineralisasi)

Larutkan kulit udang hasil deproteinasi dengan $\mathrm{HCl}$ 1,1 N menggunakan rasio 1:10 (b/v), kemudian larutan tersebut dipanaskan dengan suhu $80^{\circ} \mathrm{C}$ selama 1 jam sambil terus diaduk. Setelah dipanaskan larutan didinginkan selama 30 menit lalu disaring dengan penyaring kain sambil dicuci dengan air keran sampai $\mathrm{pH}$ nya netral, kemudian dibilas dengan aquades. Selanjutnya kulit udang dikeringkan di dalam oven selama 24 jam dan ditimbang.

c. Deasetilasi kitin menjadi kitosan

Larutkan kulit udang hasil demineralisasi dengan $\mathrm{NaOH}$ $50 \%$ menggunakan rasio $1: 10(\mathrm{~b} / \mathrm{v})$. Larutan tersebut kemudian dipanaskan dengan suhu $110^{\circ} \mathrm{C}$ selama 2 jam sambil terus diaduk. Setelah dipanaskan larutan didinginkan selama 30 menit lalu disaring dengan penyaring kain sambil dicuci dengan air keran sampai $\mathrm{pH}$ nya netral, kemudian dibilas dengan aquades. Selanjutnya kulit udang dikeringkan di dalam oven selama 24 jam dan ditimbang.

d. Karakterisasi kitosan

- Rendemen: kitosan hasil deasetilasi ditimbang lalu dihitung dengan persamaan (1).

$$
(\%)=\frac{\text { massa kitosan kering (gram) }}{\text { massa kulit udang kering (gram) }}
$$

- Kelarutan: 1 gram kitosan dilarutkan dengan $100 \mathrm{ml}$ larutan asam asetat $1 \%$ kemudian diaduk sampai larut sempurna ( $\pm 1,5$ jam).

- Derajat deasetilasi: 0,1 gram kitosan dilarutkan dengan $30 \mathrm{ml} \mathrm{HCl}$ 0,1 M kemudian ditambahkan dengan 5-6 tetes metil orange dan dititrasi menggunakan larutan $\mathrm{NaOH}$ 0,1 M sampai berubah menjadi warna jingga (metode asam basa). Derajat deasetilasi (DDA) dihitung dengan persamaan (2).

$$
D D A(\%)=\frac{\left(C_{1} V_{1}-C_{2} V_{2}\right)}{M \times 0,0994} \times 0,016
$$

dimana $C_{1}$ adalah konsentrasi larutan standar $\mathrm{HCl}, V_{1}$ adalah volume larutan standar $\mathrm{HCl}, C_{2}$ adalah konsentrasi larutan standar $\mathrm{NaOH}, V_{2}$ adalah volume larutan standar $\mathrm{NaOH}$, dan $M$ adalah berat kitosan.

\section{B. Uji Perbandingan Kitosan dan Aluminium Sulfat $45 \%$}

Uji kemampuan diawali dengan pembuatan sampel air keruh (dari analisis data sekunder), pembuatan larutan induk kitosan dan aluminium sulfat kemudian dilanjutkan dengan jar test.

a. Analisis data sekunder

Data sekunder yang digunakan adalah data kekeruhan air dari outlet bak prasedimentasi IPAM Ngagel 2. Dari data tersebut kemudian dihitung standar deviasinya sehingga didapatkan 2 rentang kekeruhan yaitu rentang kekeruhan musim kemarau dan rentang kekeruhan musim hujan.

b. Pembuatan variabel kekeruhan

Sampel air diambil dari outlet bak prasedimentasi IPAM Ngagel II yang kemudian kekeruhannya disesuaikan dengan hasil analisis data sekunder. Peningkatan kekeruhan dibuat dengan menambahkan lumpur sungai yang sudah dikeringkan sedangkan penurunan tingkat kekeruhan dibuat dengan pengenceran menggunakan aquades.

c. Pembuatan larutan koagulan

- Larutan induk alumunium sulfat 45\% dibuat dengan konsentrasi 10.000 ppm dan 20.000 ppm. Larutan induk $10.000 \mathrm{ppm}$ dibuat dengan cara melarutkan 2 gram aluminium sulfat $45 \%$ ke dalam $200 \mathrm{ml}$ aquades. Larutan induk 20.000 ppm dibuat dengan cara melarutkan 4 gram aluminium sulfat $45 \%$ ke dalam $200 \mathrm{ml}$ aquades.

- Larutan induk kitosan 5.000 ppm dibuat dengan melarutkan 0,5 gram ke dalam $100 \mathrm{ml}$ asam asetat $1 \%$.

d. Jar test

Variabel yang digunakan dalam jar test adalah kekeruhan dan dosis koagulan. Jar test dilakukan dengan kecepatan $150 \mathrm{rpm} 1$ menit, $50 \mathrm{rpm}$ selama 3 menit dan $25 \mathrm{rpm}$ selama 5 menit. Setelah itu larutan didiamkan selama 5 menit lalu dilakukan pemeriksaan kekeruhan dan $\mathrm{pH}$.

\section{Perhitungan Biaya}

Pemakaian koagulan dihitung dengan persamaan (3). Biaya penggunaan koagulan per jam dan per $\mathrm{m}^{3}$ masing-masing dihitung dengan persamaan (4) dan (5)

$$
X=\frac{Q \times D}{10^{6}}
$$

dimana $X$ adalah bahan koagulan yang digunakan (kg/jam), $Q$ adalah debit air yang diolah (liter/jam) dan $D$ adalah dosis koagulan yang digunakan $(\mathrm{ppm}=\mathrm{mg} / \mathrm{l})$.

$$
\begin{aligned}
& \text { Biaya per jam }=\text { pemakaian koagulan }(\mathrm{kg} / \mathrm{jam}) \times \text { harga per } \mathrm{kg} \\
& \text { Biaya per } \mathrm{m}^{3}=\frac{\text { biaya koagulan per jam }}{\text { debit air yang diolah }\left(\mathrm{m}^{3} / \mathrm{jam}\right)}
\end{aligned}
$$

\section{HASIL DAN PEMBAHASAN}

\section{A. Pembuatan Kitosan dari Limbah Kulit Udang}

Limbah kulit udang yang akan digunakan harus dicuci dahulu untuk menghilangkan kotoran yang menempel. Setelah dicuci, limbah kulit udang dimasukan ke dalam oven selama 24 jam untuk menghilangkan kadar airnya. Kemudian limbah kulit udang tersebut dihaluskan dengan blender. Proses ini bertujuan untuk memperbesar luas permukaan limbah kulit udang sehingga dapat memaksimalkan proses pembuatan 
kitosan.

Pada proses deproteinasi, demineralisasi dan deasetilasi terdapat proses pemanasan, pengadukan, pencucian dan pengeringan. Pemanasan berfungsi untuk mempercepat reaksi yang berlangsung. Pengadukan berfungsi untuk mencampurkan reagen agar reaksi berlangsung sempurna. Pencucian berfungsi untuk menghilangkan reagen dari kulit udang. Pengeringan berfungsi untuk menghilangkan kadar air dari proses pencucian.

a. Penghilangan protein (deproteinasi)

Kulit udang seberat 50 gram dilarutkan dengan $500 \mathrm{ml}$ $\mathrm{NaOH} 6 \%$ kemudian dipanaskan dengan suhu $100^{\circ} \mathrm{C}$ selama 2 jam sambil terus diaduk. Setelah dipanaskan larutan didinginkan selama 30 menit lalu di saring dengan penyaring kain sambil dicuci dengan air keran sampai $\mathrm{pH}$ nya netral, kemudian dibilas dengan aquades. Selanjutnya kulit udang dikeringkan di dalam oven selama 24 jam dan ditimbang. Kulit udang hasil deproteinasi adalah sebesar 31,86 gram sehingga kadar protein yang terkandung dalam kulit udang $\pm 36,28 \%$. Pada proses ini, $\mathrm{NaOH}$ berfungsi untuk memutus ikatan intermolekuler antara kitin dan protein, kemudian protein akan berikatan dengan $\mathrm{Na}+$ proteinat yang larut di dalam air [5].

b. Penghilangan mineral (demineralisasi)

Kulit udang hasil deproteinasi seberat 31,86 gram dilarutkan dengan $319 \mathrm{ml} \mathrm{HCl}$ 1,1 N kemudian larutan tersebut dipanaskan dengan suhu $80^{\circ} \mathrm{C}$ selama 1 jam sambil terus diaduk. Setelah dipanaskan larutan didinginkan selama 30 menit lalu disaring dengan penyaring kain sambil dicuci dengan air keran sampai $\mathrm{pH}$ nya netral, kemudian dibilas dengan aquades. Selanjutnya kulit udang dikeringkan di dalam oven selama 24 jam dan ditimbang. Kulit udang hasil demineralisasi adalah sebesar 15,23 gram sehingga kadar protein yang terkandung dalam kulit udang $\pm 30,46 \%$. Pada proses ini, $\mathrm{HCl}$ akan akan bereaksi dengan mineral-mineral seperti kalsium karbonat $\left(\mathrm{CaCO}_{3}\right)$ dan trikalsium fosfat $\left(\mathrm{Ca}_{3}\left(\mathrm{PO}_{4}\right)_{2}\right)$ menghasilkan gas $\mathrm{CO}_{2}$ yang hilang setelah proses pemanasan [5].

c. Deasetilasi kitin menjadi kitosan

Kulit udang hasil demineralisasi seberat 15,23 gram dilarutkan dengan $152 \mathrm{ml} \mathrm{NaOH}$ 50\% kemudian dipanaskan dengan suhu $110^{\circ} \mathrm{C}$ selama 2 jam sambil terus diaduk. Setelah dipanaskan larutan didinginkan selama 30 menit lalu disaring dengan penyaring kain sambil dicuci dengan air keran sampai pH nya netral, kemudian dibilas dengan aquades. Selanjutnya kulit udang dikeringkan di dalam oven selama 24 jam dan ditimbang. Kulit udang hasil deasetilasi adalah sebesar 13,74 gram. Kulit udang ini sudah dapat disebut dengan kitosan. Pada proses ini, $\mathrm{NaOH}$ pekat akan memutus ikatan hidrogen yang kuat antar gugus asetil $\left(-\mathrm{COCH}_{3}\right)$ dengan atom nitrogen pada gugus asetamida $\left(\mathrm{NH}-\mathrm{COCH}_{3}\right)$ sehingga gugus asetamida berubah menjadi gugus amina $\left(-\mathrm{NH}_{2}\right)$ [6].

d. Karakterisasi kitosan

- Rendemen yang dihasilkan adalah sebesar 27\%.

$$
\text { rendemen }(\%)=\frac{13,74 \mathrm{gram}}{50 \mathrm{gram}} \times 100 \%=27 \%
$$

- Kitosan larut dengan sempurna dalam asam asetat..

- Derajat deasetilasi kitosan adalah sebesar 80,48\% (volume $\mathrm{NaOH}=25 \mathrm{ml}$ ).

$$
D D A(\%)=\frac{(0,1 \mathrm{M} \times 30 \mathrm{ml})-(0,1 \mathrm{M} \times 25 \mathrm{ml})}{0,1 \text { gram } \times 0,0994} \times 0,016=80,48 \%
$$

karena derajat deasetilasi sudah lebih dari 70\% sehingga kulit udang dari proses deasetilasi sudah dapat disebut sebagai kitosan.

\section{B. Hasil Analisis Data Sekunder}

Variabel kekeruhan ditentukan berdasarkan data kekeruhan air dari outlet bak prasedimentasi pada bulan Juli 2015, Agustus 2015, September 2015 yang mewakili musim kemarau dan pada bulan Januari 2016, Febuari 2016, Maret 2016, April 2016 yang mewakili musim hujan. Dari data tersebut kemudian diambil rentang nilai kekeruhan yang mewakili musim kemarau dan musim hujan. Rentang nilai dihitung dengan menggunakan standar deviasi. Dari hasil perhitungan didapat rentang kekeruhan sebesar 7,5 - 12 NTU untuk musim kemarau dan 37,5 - 97 NTU untuk musim hujan.

\section{Uji Efektivitas dan Efisiensi Aluminium Sulfat 45\%}

Aluminium sulfat $45 \%$ yang dipakai adalah aluminium sulfat dalam bentuk padat. Kekeruhan awal sampel air yang di ambil dari outlet bak prasedimentasi adalah sebesar 20,4 NTU, kemudian sampel diencerkan dengan 9 liter aquades hingga kekeruhan sampel turun menjadi 12 NTU (rentang kekeruhan musim kemarau (7,5 - 12 NTU)). pH sampel setelah diencerkan adalah sebesar 7,77. Variabel dosis yang digunakan adalah sebesar 5 ppm, 10 ppm, 20 ppm, 30 ppm, 40 ppm dan 50 ppm.

Pada saat pengadukan cepat (150 rpm, 1 menit) koagulan yang ditambahkan diaduk dengan kecepatan tinggi untuk mencampurkan koagulan dengan sampel air, setelah 1 menit belum terlihat perubahan fisik atau pembentukan flok pada sampel air. Pada pengadukan lambat (50 rpm, 3 menit) mikroflok mulai terbentuk dan mulai turun ke dasar gelas beaker, kemudian saat kecepatan pengadukan diturunkan (25 rpm, 5 menit) mikroflok bergabung menjadi makroflok dan mulai mengendap. Endapan atau lumpur yang dihasilkan berwarna putih kecoklatan. Warna putih kecoklatan menunjukkan bahwa partikel yang paling banyak terkandung di dalam sampel adalah partikel kaolin. Lumpur alum yang dihasilkan mengandung $\mathrm{Al}, \mathrm{Fe}, \mathrm{Mg}$ dan $\mathrm{Ca}$ [7].

Pada saat proses koagulasi, mekanisme yang terjadi adalah sweep coagulation. Aluminium sulfat terhidrolisis menjadi $\mathrm{Al}(\mathrm{OH})_{3}$ atau presipitat yang akan menjebak partikel koloid dan membentuk flok [8]. Rentang $\mathrm{pH}$ optimum aluminium sulfat berada di $\mathrm{pH} 4,5-8$. Hal ini terjadi karena presipitat $\mathrm{Al}$ $(\mathrm{OH})_{3}$ baru dominan pada $\mathrm{pH} \mathrm{4,5}-8$. Pada $\mathrm{pH}<4,5$ dan $>8$ sebagian besar aluminium sulfat hadir sebagai spesimen terlarut [9]. Penurunan kekeruhan dan $\mathrm{pH}$ yang terjadi dapat dilihat di Gambar 1 dan Gambar 2. 


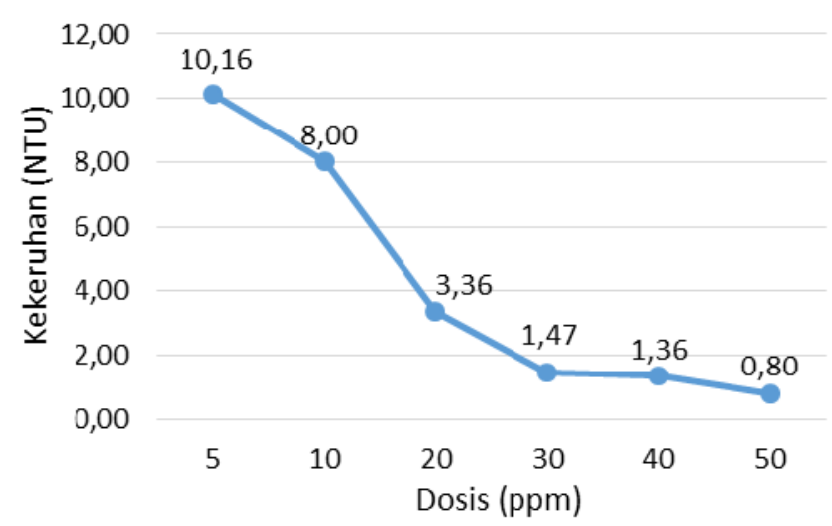

Gambar 1. Penurunan kekeruhan dengan aluminium sulfat $45 \%$ (dosis 5-50 ppm) pada kekeruhan 12 NTU.

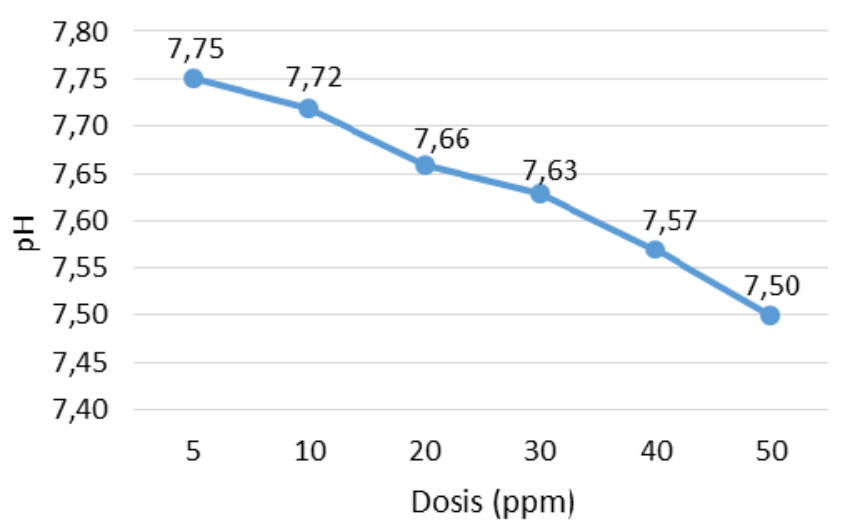

Gambar 2. Penurunan pH dengan aluminium sulfat 45\% (dosis 550 ppm) pada kekeruhan 12 NTU.

Gambar 1 menunjukkan penurunan kekeruhan terbesar terjadi pada dosis $50 \mathrm{ppm}$. Kekeruhan turun dari $12 \mathrm{NTU}$ menjadi 0,80 NTU atau turun sebesar 93,33\%. Namun karena penurunan kekeruhan dari dosis $30 \mathrm{ppm}$ ke 50 ppm tidak terlalu jauh, sehingga untuk menghemat biaya produksi dosis optimum yang dipilih adalah $30 \mathrm{ppm}$. Pada dosis $30 \mathrm{ppm}$ kekeruhan turun dari 12 NTU menjadi 1,47 NTU atau turun sebesar $87,75 \%$.

Gambar 2 menunjukkan pada dosis optimum (30 ppm) pH turun dari 7,87 menjadi 7,63 atau turun sebesar 3,05\%. Penurunan $\mathrm{pH}$ terjadi karena aluminium sulfat mengandung sulfur yang bersifat sifat asam [7]. Selain itu dalam proses pembentukan flok, aluminium sulfat bereaksi dengan alkalinitas air sehingga semakin lama $\mathrm{pH}$ air akan menjadi semakin asam [10].

Setelah itu dilakukan jar test dengan variabel kekeruhan musim hujan. Kekeruhan awal sampel air yang di ambil dari outlet bak prasedimentasi adalah sebesar 54 NTU, kemudian sampel ditambahkan dengan 12 gram lumpur sungai yang sudah dikeringkan hingga kekeruhan sampel naik menjadi 80 NTU (rentang kekeruhan musim hujan (37,5 - 97 NTU)). pH sampel setelah ditambahkan dengan lumpur adalah sebesar 7,16. Variabel dosis yang digunakan adalah $60 \mathrm{ppm}, 70 \mathrm{ppm}$, 80 ppm, 90 ppm, 100 ppm, dan 110 ppm.

Pada saat jar test dengan kekeruhan tinggi, flok menjadi lebih banyak dan lebih cepat terbentuk. Hal ini disebabkan karena pada kekeruhan tinggi, jumlah partikel yang terdapat air lebih banyak sehingga kontak antara presipitat dan partikel akan lebih mudah terjadi [10].

Setelah pengendapan, endapan atau lumpur yang terbentuk berupa lapisan berwarna putih kecoklatan. Endapan yang berwarna putih kecoklatan ini menunjukkan bahwa partikel yang paling banyak terkandung di dalam sampel adalah partikel kaolin. Penurunan kekeruhan dan $\mathrm{pH}$ yang terjadi dapat dilihat pada Gambar 3 dan 4.

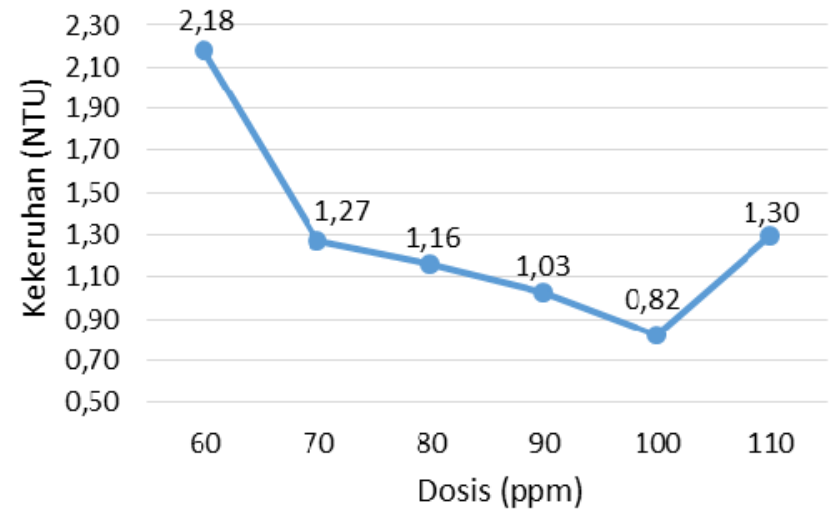

Gambar 3. Penurunan kekeruhan dengan aluminium sulfat $45 \%$ (dosis 60-110 ppm) pada kekeruhan 80 NTU.

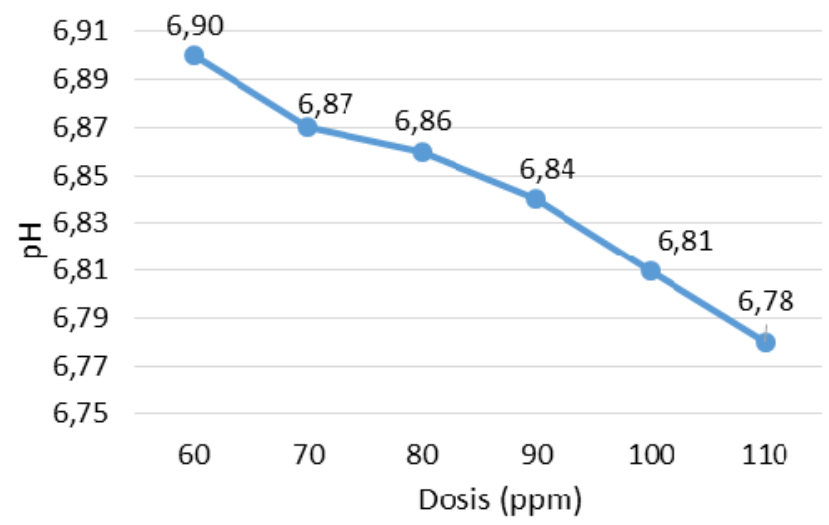

Gambar 4. Penurunan $\mathrm{pH}$ dengan aluminium sulfat $45 \%$ (dosis 60 110 ppm) pada kekeruhan 80 NTU.

Gambar 3 menunjukkan bahwa penurunan kekeruhan terbesar terjadi pada dosis $100 \mathrm{ppm}$. Kekeruhan turun dari 80 NTU menjadi 0,82 NTU atau turun sebesar 98,98\%. Namun dosis optimum yang dipilih adalah $70 \mathrm{ppm}$. Pada dosis $70 \mathrm{ppm}$ kekeruhan turun menjadi 1,27 NTU atau turun sebesar 98,41\%. Dosis optimum menjadi lebih besar disebabkan karena jumlah partikel pada kekeruhan 80 NTU lebih banyak sehingga diperlukan lebih banyak koagulan untuk mendestabilisasi partikel.

Gambar 4 menunjukkan pada dosis optimum (70 ppm) pH turun dari 7,16 menjadi 6,87 atau turun sebesar 4,05\%. Dari Gambar 2 dan 4 dapat disimpulkan bahwa penambahan dosis aluminium sulfat berbanding lurus dengan penurunan $\mathrm{pH}$. 


\section{Uji Efektivitas dan Efisiensi Kitosan}

Kekeruhan awal sampel air yang di ambil dari outlet bak prasedimentasi adalah sebesar 20,4 NTU, kemudian sampel diencerkan dengan 9 liter aquades hingga kekeruhan sampel turun menjadi 12 NTU (rentang kekeruhan musim kemarau (7,5 - 12 NTU)). pH sampel setelah diencerkan adalah sebesar 7,77. Variabel dosis yang digunakan adalah sebesar $1 \mathrm{ppm}, 2$ ppm, 3 ppm, 4 ppm, 5 ppm dan 6 ppm.

Pada saat pengadukan lambat ( $25 \mathrm{rpm}, 5$ menit) mikroflok yang terbentuk semakin banyak, namun tidak menggumpal menjadi satu. Hal ini dapat disebabkan karena partikel utama penyebab kekeruhan adalah partikel kaolin (dilihat dari endapan yang berwarna putih). Kitosan tidak dapat membentuk agregat yang baik dengan partikel kaolin, sehingga air dengan kandungan partikel kaolin harus ditambahkan dengan partikel bentonit [11].

Pada saat proses koagulasi dengan kitosan, mekanisme yang terjadi adalah mekanisme adsorption and interparticle bridging. Pada proses ini gugus amina $\left(-\mathrm{NH}_{2}\right)$ akan mengikat ion $\mathrm{H}^{+}$dari asam asetat sehingga membentuk $\mathrm{NH}_{3}{ }^{+}$. Gugus ini kemudian akan teradsorpsi lalu berikatan dengan parikel koloid yang bemuatan negatif dan membentuk jembatan polimer yang menggabungkan antar partikel koloid sehingga terbentuk flok [4]. Penurunan kekeruhan dan $\mathrm{pH}$ yang terjadi dapat dilihat pada Gambar 5 dan 6.

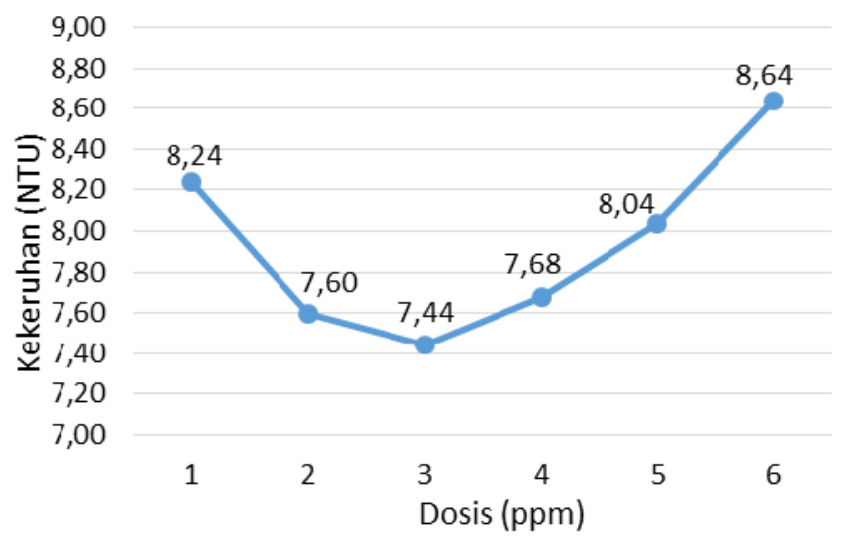

Gambar 5. Penurunan kekeruhan dengan kitosan (dosis 1-6 ppm) pada kekeruhan 12 NTU.

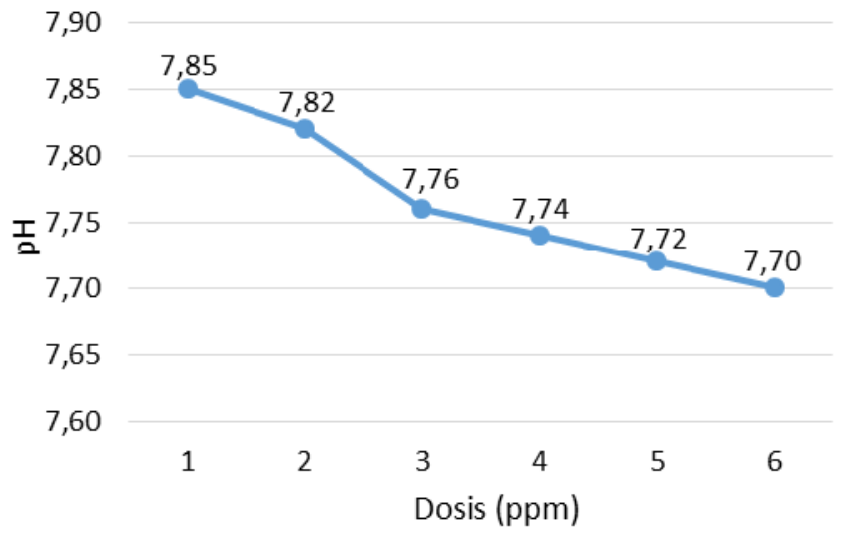

Gambar 6. Penurunan $\mathrm{pH}$ dengan kitosan (dosis 1-6 ppm) pada kekeruhan 12 NTU.
Gambar 5 menunjukkan bahwa dosis optimum kitosan ada pada konsentrasi 3 ppm dengan kekeruhan akhir sebesar 7,44 NTU atau turun sebesar 38\%. Penurunan kekeruhan dengan kitosan tidak terlalu besar karena pembentukan flok yang kurang optimum, namun kekeruhan akhir hasil jar test kitosan masih di bawah 10 NTU sehingga air hasil jar test masih dapat di lanjutkan ke pengolahan selanjutnya yaitu filter.

Gambar 6 menunjukkan pada dosis optimum (3 ppm) $\mathrm{pH}$ turun dari 7,87 menjadi 7,84 atau turun sebesar 0,38\%. Penurunan $\mathrm{pH}$ ini disebabkan oleh konsentrasi asam asetat $1 \%$ pada larutan induk kitosan yang digunakan untuk melarutkan kitosan.

Setelah itu dilakukan jar test dengan variabel kekeruhan musim hujan. Kekeruhan awal sampel air yang di ambil dari outlet bak prasedimentasi adalah sebesar 31,7 NTU, kemudian sampel ditambahkan dengan 20 gram lumpur sungai yang sudah dikeringkan hingga kekeruhan sampel naik menjadi 80 NTU (rentang kekeruhan musim hujan (37,5 - 97 NTU)). pH sampel setelah ditambahkan dengan lumpur adalah sebesar 7,02. Variabel dosis yang digunakan adalah 1-12 ppm.

Pada jar test dengan kekeruhan tinggi terjadi pembentukan makroflok, karena pada kekeruhan yang tinggi proses koagulasi dan flokulasi akan berlangsung dengan lebih mudah sehingga flok akan terbentuk dengan mudah. Lalu lumpur sungai yang ditambahkan mengandung partikel bentonit sehingga mempermudah kitosan dalam membentuk makroflok. Penurunan kekeruhan dan $\mathrm{pH}$ yang terjadi dapat dilihat di Gambar 7 dan Gambar 8.

Gambar 7. Penurunan kekeruhan dengan kitosan (dosis 1-12 ppm)

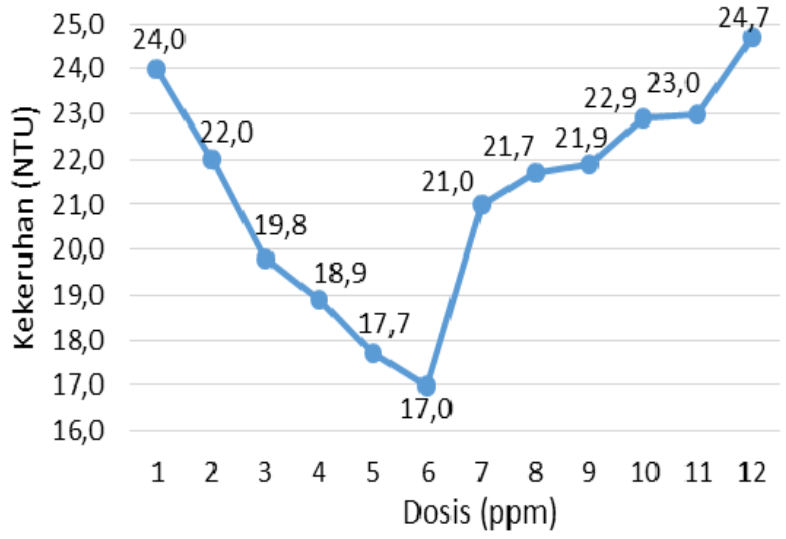

pada kekeruhan 80 NTU.

Gambar 7 menunjukkan bahwa dosis optimum kitosan ada pada konsentrasi $6 \mathrm{ppm}$ dengan kekeruhan akhir sebesar 17 NTU atau turun sebesar 78,75\%. Gambar 8 menunjukkan pada dosis optimum (6 ppm) pH turun dari 7,02 menjadi 6,96 atau turun sebesar $0,85 \%$. Penurunan $\mathrm{pH}$ yang terjadi pada jar test dengan kekeruhan 80 NTU (0,85\%) tidak sebesar penurunan $\mathrm{pH}$ pada jar test dengan kekeruhan 12 NTU $(1,4 \%)$ karena pada jar test dengan kekeruhan 80 NTU, makroflok mudah terbentuk sehingga ion $\mathrm{H}^{+}$banyak berikatan dengan gugus amina dan menyebabkan kadar ion $\mathrm{H}^{+}$di dalam air berkurang. 


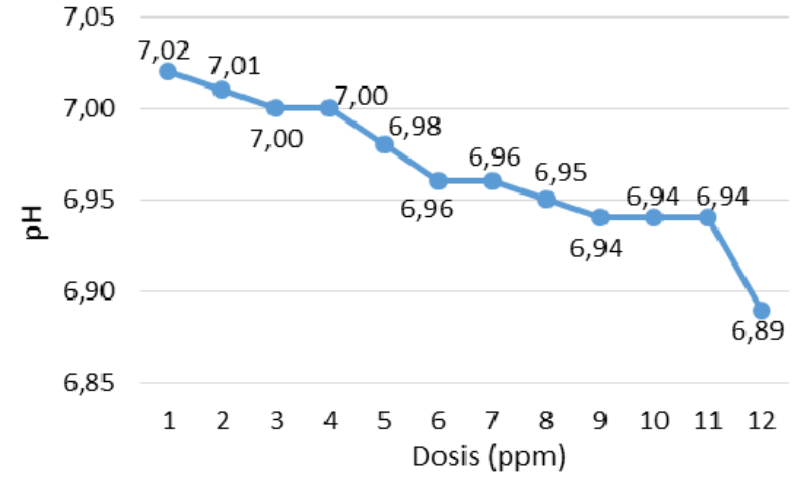

Gambar 8. Penurunan $\mathrm{pH}$ dengan kitosan (dosis 1-12 ppm) pada kekeruhan 80 NTU

\section{E. Perbandingan Biaya}

Debit pengolahan $=850 \mathrm{l} / \mathrm{s}=3.060 \mathrm{~m}^{3} / \mathrm{jam}$

Pemakaian aluminium sulfat $45 \%$ per jam:

- Musim kemarau $=91,8 \mathrm{~kg} / \mathrm{jam}$

- Musim hujan $\quad=214,2 \mathrm{~kg} / \mathrm{jam}$

Pemakaian aluminium sulfat $45 \%$ per hari:

- Musim kemarau $=91,8 \mathrm{~kg} / \mathrm{jam} \times 24 \mathrm{jam} / \mathrm{hari}$ $=2.203,2 \mathrm{~kg} / \mathrm{hari}=2,2$ ton $/$ hari

- Musim hujan $=214,2 \mathrm{~kg} / \mathrm{jam} \times 24 \mathrm{jam} / \mathrm{hari}$ $=5.140,8 \mathrm{~kg} / \mathrm{hari}=5,14$ ton $/$ hari

Harga aluminium sulfat $45 \%=$ Rp. $1.600,00 / \mathrm{kg}$

Biaya penggunaan aluminium sulfat $45 \%$ per jam:

- Musim kemarau = 91,8 kg/jam $\times$ Rp. 1.600,00/kg $=R p .146 .880,00$

- Musim hujan $=214,2 \mathrm{~kg} / \mathrm{jam} \times \mathrm{Rp} .1 .600,00 / \mathrm{kg}$ $=$ Rp. 324.720,00

Biaya penggunaan aluminium sulfat $45 \%$ per hari:

- Musim kemarau $=2.203,2 \mathrm{~kg} /$ hari $x$ Rp. $1.600,00 / \mathrm{kg}$

$$
=R p .3 .525 \cdot 120,00
$$

- Musim hujan $=5.140,8 \mathrm{~kg} /$ hari $\times$ Rp. 1.600,00/kg $=R p .8 \cdot 225.280,00$

Harga kitosan dari penelitian $=$ Rp. $2 \cdot 167.700,15 / \mathrm{kg}$

Harga kitosan komersil = Rp. 540.000,00/kg

Untuk perhitungan biaya dengan kitosan, harga yang digunakan adalah harga kitosan komersil agar perbandingan biaya selaras.

Pemakaian kitosan per jam:

- Musim kemarau $=9,18 \mathrm{~kg} / \mathrm{jam}$

- Musim hujan $\quad=18,36 \mathrm{~kg} / \mathrm{jam}$

Pemakaian kitosan per hari:

- Musim kemarau = 9,18 kg/jam x $24 \mathrm{jam} / \mathrm{hari}$

$$
=220,3 \mathrm{~kg} / \text { hari }=0,2 \text { ton } / \text { hari }
$$

- Musim hujan $=18,36 \mathrm{~kg} / \mathrm{jam} \times 24 \mathrm{jam} / \mathrm{hari}$

$$
=440,64 \mathrm{~kg} / \text { hari }=0,4 \text { ton } / \text { hari }
$$

Biaya penggunaan kitosan per jam:

- Musim kemarau = 9,18 kg/jam $\times$ Rp. $540.000,00 / \mathrm{kg}$ $=R p \cdot 4.957 .200,00$

- Musim hujan = 18,36 kg/jam $x$ Rp. $540.000,00 / \mathrm{kg}$ $=$ Rp. 9.914.400,00
Biaya penggunaan kitosan per hari:

$$
\begin{aligned}
\text { - Musim kemarau } & =220,3 \mathrm{~kg} / \mathrm{hari} \times \mathrm{Rp} .540 .000,00 / \mathrm{kg} \\
& =R p .118 .972 .800,00 \\
\text { - Musim hujan }= & 440,64 \mathrm{~kg} / \mathrm{hari} \times \mathrm{Rp} .540 .000,00 / \mathrm{kg} \\
= & \text { Rp. } 237.945 .600,00
\end{aligned}
$$

\section{KESIMPULAN/RINGKASAN}

Kesimpulan yang diperoleh dari penelitian ini adalah sebagai berikut:

1. Koagulan yang paling efektif adalah aluminium sulfat $45 \%$ dengan penurunan kekeruhan sebesar $87,75 \%$ pada kekeruhan 12 NTU dan 98,41\% pada kekeruhan 80 NTU.

2. Koagulan yang paling efisien adalah kitosan dengan dosis optimum 3 ppm pada kekeruhan 12 NTU dan 6 ppm pada kekeruhan 80 NTU.

3. Koagulan dengan biaya pemakaian paling murah adalah aluminium sulfat 45\%, yaitu sebesarPada musim kemarau, biaya pemakaian aluminium sulfat $45 \%$ adalah sebesar Rp. 3.525.120,00/hari, pada musim kemarau \%. Pada musim hujan, biaya pemakaian aluminium sulfat 45\% adalah sebesar Rp. 8.225.280,00/hari, aluminium sulfat 17\% sebesar Rp. 15.863.040,00/hari, dan kitosan sebesar Rp. 237.945.600,00/hari, sehingga koagulan yang paling murah adalah aluminium sulfat 45\%.Tuliskan kesimpulan dari penelitian yang artikelnya Anda tulis ini tanpa mengulang hal-hal yang telah disampaikan di Abstrak. Kesimpulan dapat diisi pula tentang pentingnya hasil yang dicapai dan saran untuk aplikasi dan pengembangannya.

\section{UCAPAN TERIMA KASIH}

Penulis C.D.T. mengucapkan terima kasih kepada PDAM Surya Sembada Surabaya yang telah memberikan fasilitas untuk melaksanakan penelitian ini.

\section{DAFTAR PUSTAKA}

[1] A. N. Novitasari dan E. S. Soedjono, "Analisis identifikasi \& inventarisasi sumber pencemar di Kali Surabaya," dalam Prosiding Seminar Nasional Manajemen Teknologi XXII, Surabaya (2015).

[2] C.-Y. Yin, "Emerging usage of plant-based coagulant for water and wastewater," Process Biochemistry., Vol. 45, (2010) 1437-1444.

[3] Mu'minah, "Aplikasi kitosan sebagai koagulan untuk penjernihan air keruh,” Thesis, Fakultas Matematika dan Ilmu Pengetahuan Alam., Institut Teknologi Bandung., Bandung, Indonesia (2008).

[4] F. Renault, B. Sancey, P.-M. Badot, and G. Crini, "Chitosan for coagulation/flocculation processes - An eco-friendly approach," European Polymer Journal., Vol. 45, (2008) 1337-1348.

[5] D. N. R. Rifai, "Isolasi dan identifikasi kitin, kitosan dari cangkang hewan mimi menggunakan spektrofotometri infra merah," Jurnal Alchemy., Vol. 2, (2010) 140-157.

[6] E. Savitri, N. Soeseno, T. Adiarto, "Sintesis kitosan, poli (2-amina-2deoksi-D-glukosa), skala pilot project dari limbah kulit udang sebagai bahan baku alternatif pembuatan biopolimer," dalam Prosiding Seminar Nasional Pengembangan Teknologi Kimia untuk Pengolahan Sumber Daya Alam Indonesia, Yogyakarta (2010).

[7] R. Amir, "Penentuan dosis optimum aluminium sulfat dalam pengolahan air Sungai Cileueur Kota Ciamis dan pemanfaatan resirkulasi lumpur 
dengan parameter pH, warna, kekeruhan dan TSS," Tugas akhir, Fakultas Teknik Sipil dan Lingkungan., Institut Teknologi Bandung., Bandung, Indonesia (2010).

[8] I. D. A. Sutapa, "Efisiensi proses koagulasi di kompartemen flokulator tersusun seri dalam sistem pengolahan air bersih," dalam Prosiding Seminar Nasional Teknik Kimia, Yogyakarta (2010).

[9] S. W. Rahmawati, B. Iswanto, dan Winarni, "Pengaruh pH pada proses koagulasi dengan koagulan aluminium sulfat dan ferri klorida,” Jurnal Teknik Lingkungan., Vol. 5, (2009) 40-45.

[10] F. Rosariawari dan M. Mirwan, "Efektivitas PAC dan tawas untuk menurunkan kekeruhan pada air permukaan,” Tugas akhir, Fakultas Teknik Sipil dan Perencanaan., Universitas Pembangunan Nasional "Veteran”., Surabaya, Indonesia (2013).

[11] C. Huang and Y. Chen, "Coagulation of colloidal particles in water by chitosan,” Journal of Chemical Technology and Biotechnology., Vol. 66, (1996) 227-232.piting menjadi kitosan sebagai 